\title{
Zona de Processamento de Exportação (ZPE), reestruturação econômica e estratégia global de expansão
}

Export Processing Zone (EPZ), economic restructuring and global expansion strategy

Zona de Procesamiento para la Exportación (ZPE), reestructuración económica y estrategia global de expansión

L'expansion des Zones Franches d'Exportation (ZPES), restructuration

économique et stratégie d'expansion mondiale

Jean da Silva Cruz e Antonio Nivaldo Hespanhol

\section{(2) OpenEdition}

\section{Journals}

\section{Edição electrónica}

URL: https://journals.openedition.org/espacoeconomia/19139

DOI: 10.4000/espacoeconomia.19139

ISSN: 2317-7837

\section{Editora}

Núcleo de Pesquisa Espaço \& Economia

Refêrencia eletrónica

Jean da Silva Cruz e Antonio Nivaldo Hespanhol, «Zona de Processamento de Exportação (ZPE), reestruturação econômica e estratégia global de expansão», Espaço e Economia [Online], 21 | 2021, posto online no dia 12 julho 2021, consultado o 17 julho 2021. URL: http://journals.openedition.org/ espacoeconomia/19139; DOI: https://doi.org/10.4000/espacoeconomia.19139

Este documento foi criado de forma automática no dia 17 julho 2021.

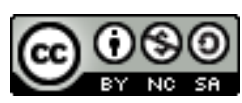

Espaço e Economia - Revista brasileira de geografia econômica est mise à disposition selon les termes de la licence Creative Commons Attribution - Pas d'Utilisation Commerciale - Partage dans les Mêmes Conditions 4.0 International. 


\title{
Zona de Processamento de Exportação (ZPE), reestruturação econômica e estratégia global de expansão
}

\author{
Export Processing Zone (EPZ), economic restructuring and global expansion \\ strategy \\ Zona de Procesamiento para la Exportación (ZPE), reestructuración económica y \\ estrategia global de expansión \\ L'expansion des Zones Franches d'Exportation (ZPES), restructuration \\ économique et stratégie d'expansion mondiale
}

Jean da Silva Cruz e Antonio Nivaldo Hespanhol

\section{Introdução}

1 A utilização das Zonas de Processamento de Exportações (ZPEs) como modelo político e econômico no mundo não é recente. Entretanto, no decorrer do ano de 1934, esse instrumento foi implantado nos EUA nos moldes contemporâneos por meio de uma adaptação de Zona de Livre Comércio (ZLC) sob o princípio da extraterritorialidade, conforme destacam Egler (1991) e Silva (1993).

2 Na segunda metade do século $\mathrm{XX}$, a expansão desse modelo de política econômica industrial foi significativa em algumas regiões do mundo (União Europeia, Ásia, África e nas Américas Central e do Sul). Duas forças são preconizadas para a difusão das ZPEs em um contexto de plena abertura econômica, quais sejam:

3 1) como ferramenta de política econômica industrial, da qual se beneficiariam principalmente os países subdesenvolvidos, atraindo os chamados Investimentos Estrangeiros Diretos (IEDs) para a modernização e a difusão tecnológica 
visando sua inserção de forma competitiva - em busca por equiparação com os países "desenvolvidos" - nas redes de produção globais e da troca; e

4 2) como estratégia alternativa de política industrial e de desenvolvimento pelos governos dos países subdesenvolvidos como forma de solução para os problemas econômicos, sociais e regionais.

5 A partir disso, compreendemos que, diante das mudanças das práticas do poder material, criam-se novas estratégias de desenvolvimento, inserindo os novos arranjos espaciais produtivos em um processo de globalização neoliberal. As ZPEs, no contexto de um mercado globalizante, representam um projeto neoliberal de integração vertical regional que, ao adotar esse instrumento de política econômica como estratégia de desenvolvimento, abre as fronteiras. Assim, delimitam-se "áreas" ou espaços específicos cujo objetivo é estabelecer condições ou atmosfera de "livre comércio" assentada e/ou regida por normas e regras específicas de mercado com um aparato político-discursivo de integração por igual na fragmentação da produção.

6 Nesse sentido, percebe-se uma política de estado mais flexível, sobretudo na criação de espaços diferenciados, conforme as condições gerais de produção (CGP) para o favorecimento da acumulação capitalista pautada na ideia de produção de estratégia e ligada a certas políticas de desenvolvimento (PAINTNER, 2005).

7 Diante dessa guisa introdutória, temos como proposta, em um primeiro momento, analisar as ZPEs como estratégia para promover o desenvolvimento em um contexto marcado pelo processo de reestruturação econômica. Em um segundo momento, esboçaremos sua definição e sua estratégia político-discursiva global de expansão para algumas regiões do mundo. Por último, analisaremos as ZPEs enquanto um projeto neoliberal de integração vertical regional que visa estabelecer um modelo específico de desenvolvimento em um sistema global altamente especializado e hierarquizado.

8 Para a operacionalização deste artigo e a consecução de seus objetivos, realizou-se um levantamento bibliográfico, propiciando construir um arcabouço das diversas perspectivas acerca da problemática em questão, e uma análise com base em fontes documentais - "de primeira e segunda mão"1 - sobre as ZPEs disponibilizadas em sítios web oficiais, tais como: United Nations Conference on Trade and Development (UNCTAD), The Word Bank (Banco Mundial); Ministério do Desenvolvimento, Indústria e Comércio Exterior (MDIC), Conselho Nacional das Zonas de Processamento de Exportação (CZPE) e Associação Brasileira de Zonas de Processamento de Exportação (ABRAZPE).

\section{Reestruturação econômica e as Zonas de Processamento de Exportação (ZPEs) como estratégia para promover o desenvolvimento}

9 Nas últimas três décadas, ocorreram profundas transformações na ordem política e econômica, gerando novas configurações nos arranjos espaciais produtivos em âmbito mundial. Essas transformações, para alguns autores ${ }^{2}$, decorreram da passagem do regime de acumulação fordista para o regime de acumulação flexível e da consolidação de uma globalização neoliberal.

Ocorreram mudanças nos métodos de produção e na organização industrial, bem como na postura do Estado, via liberalização do comércio e das finanças, associada às rápidas 
mudanças no padrão tecnológico nos processos de inovação, os quais provocaram a reestruturação econômica e alterações na divisão internacional do trabalho.

Diante desse cenário, Benko (2009) ressalta o aparecimento de uma "nova geografia econômica" ou de uma "nova geografia industrial". Todavia, para Dinken (2010), essa nova realidade política e econômica permitiu a reconfiguração de um novo mapa geoeconômico em escala global.

12 Contudo, o fato mais marcante no seio dessas mudanças na ordem política e econômica do capitalismo em via de reestruturação foi a redefinição do mapa econômico industrial com implicações nas diversas escalas.

13 Fernández (2018) ressalta a retomada das regiões/localidades enquanto escalas indispensáveis para a compreensão do processo de reestruturação e dinamização do capitalismo, bem como de sua utilização como instrumento de desenvolvimento ${ }^{3}$.

14 A compreensão do processo de reestruturação e dinamização do capitalismo contemporâneo, tem sido reinterpretada com base na antiga noção de clusters ou distritos industrias ${ }^{4}$, bem como a partir de uma gama de novos termos, como região inteligente, cooperação, capital humano, processo endógeno, desenvolvimento local etc. Esses velhos e novos termos surgem em decorrência do aparecimento de novos tipos de arranjos e/ou aglomerações produtivas regionais/locais como fator estratégico para o processo de reestruturação e desenvolvimento do capitalismo contemporâneo, tais como as aglomerações tecnológicas (ex.: Silicon Valley), as artesanais ou de Pequenas e Médias Empresas - PME (Terceira Itália) e as aglomerações financeiras e de serviços nas grandes metrópoles (BENKO, 2009; FERNÁNDEZ, 2018; HAESBAERT, 2010).

Assim, do menor distrito italiano às megalópoles mundiais, o novo paradigma tecnológico da "especialização flexível" impulsionaria não apenas o retorno das usinas e dos escritórios para as zonas urbanas, mas também a retomada do crescimento quantitativo das metrópoles: forma espacial finalmente encontrada na saída da crise do fordismo. A futura hierarquia das cidades e regiões urbanas mundiais resultaria da estratégia interna desses distritos ou conjunto de distritos (BENKO, 2009, p. 119).

15 Essa linha de compreensão dos novos distritos industriais ou de "especialização flexível" privilegia a força do mercado e o papel da globalização frente ao processo de inovação tecnológica (comunicação e transporte) e às relações comerciais entre as firmas, como indispensáveis para a reestruturação econômica na reconfiguração da geografia econômica e dos fatores endógenos, conforme salienta Teixeira (2008).

No entanto, Benko (2002) rechaça essa nova retomada enquanto uma "nova ortodoxia" em virtude de as apreensões se encaminharem quase que cegamente no processo de desenvolvimento regional endógeno. Todavia, na mesma linha crítica, Brandão (2012) salienta que há certa banalização do enfoque do desenvolvimento regional, reduzindo-o ao lugar-comum e, desse modo, cristalizando os debates em um "pensamento único localista", ou melhor, ancorado unicamente no local e nas ações empreendedoras dos agentes, que mobilizariam as forças endógenas de qualquer localidade.

17 Enquanto instrumento de desenvolvimento, segundo Cano (2010), essa abordagem tem como resultado o abandono de políticas de longo prazo, sejam elas voltadas ao desenvolvimento industrial ou às políticas de desenvolvimento setoriais e regionais. As opções, segundo o mesmo autor, são estratégias de políticas industriais com anseios extremamente "curtoprazistas". Em outras palavras, ignoram-se as opções estratégicas 
de longo prazo e passam-se a tratá-las por meio de políticas macroeconômicas de curto prazo, isto é, do tipo aqui e agora.

Em contrapartida, Benko (2002), Harvey (1989), Lipietz (1988) e Lipietz e Leborgne (1988) analisam o processo de reestruturação econômica como decorrência da crise estrutural do capitalismo face ao colapso do modelo de organização da indústria e do regime de acumulação fordista-keynesiano. Desse modo, a reestruturação econômica via acumulação flexível - e suas estratégias tinham como objetivo buscar uma saída da crise e da contradição inerente à acumulação capitalista face à rigidez apresentada pelo regime fordista. Em outros termos, a "flexibilização" foi uma resposta à crise, com o objetivo de promover a retomada da lucratividade (FUINI, 2017).

Essa transição foi acompanhada, de acordo com Harvey (1989), via solução financeira, devido ao florescimento e transformação do mercado financeiro que passou a assumir um papel fundamental para a acumulação capitalista. Igualmente, outra saída, conforme Benko (2002), foi uma solução capitalista de racionalização/flexibilização que se desdobrou para novas fontes de produtividade, complexificação da concorrência intercapitalista, reconfiguração internacional da divisão do trabalho.

Em consequência, ocorreram mudanças na composição intersetorial da acumulação, transferência de plantas industriais para regiões de baixos salários, com tendência à utilização de plantas industriais menores, ou seja, tudo para viabilizar um processo de trabalho mais flexível e com o máximo de economia quanto aos custos de produção.

21 Dentro dessa linha de compreensão, o que estaria em jogo nesse processo de reestruturação econômica e seus impactos nas geografias econômicas, conforme Teixeira (2008), seria a internacionalização das atividades das grandes empresas, implicando na especialização/hierarquização que transcende os limites das cidades e das regiões. Nesse sentido, a coordenação entre empresas corresponde, na verdade, a um tipo de relação capital-trabalho prevalecente no território.

A "flexibilidade" seria uma tendência geral para os autores do "pensamento único localista". Entretanto, para Lipietz e Leborgne (1988), essa tendência não atinge todos os territórios, mas se orienta para uma flexibilidade do contrato salarial no que diz respeito ao processo de produção, havendo a tendência à desintegração vertical. Destacam-se, ainda, a flexibilização das relações capital-trabalho e o estabelecimento de relações comerciais mais "violentas", fazendo com que os diferentes sistemas produtivos locais adotassem estratégias defensivas em alguns casos e ofensivas em outros.

23 Lipietz e Leborgne (1988) ressaltam que a busca da superação da crise foi constituída em um modelo de desenvolvimento - ancorado em um paradigma industrial de especialização flexível - de natureza territorializada; entretanto, apresentando resultados de diferentes combinações: integração, desintegração ou quase-integração vertical, integração ou desintegração territorial. Dessa forma, constata-se uma natureza mais complexa, não atribuída diretamente ao papel da tecnologia nem das relações profissionais como determinantes na conformação dos novos arranjos espaciais produtivos.

24 Estamos, nesse sentido, diante de transformações de natureza complexa em um mundo cada vez mais multifacetado e multiescalar. Lipietz e Leborgne (1988), Harvey (1989) e Benko (2002) argumentam que a construção de um mercado está longe de ser um 
processo único e homogêneo, mas que constitui um processo de desintegração econômica vertical no âmbito internacional.

As reestruturações econômicas e suas implicações nos diferentes arranjos espaciais produtivos se articulam em um processo geoestratégico de especialização e hierarquização.

Brandão (2012) salienta que os circuitos produtivos regionais/locais são constantemente recriados e a eles são atribuídos novos usos. Esses novos usos, por sua vez, são inseridos em diferentes fases do processo de produção de acordo com seus níveis tecnológicos e de qualificação, ou melhor, conforme suas condições gerais de produção (CGP) 5 .

O espaço global, argumenta Santos (2009), sob a lógica do grande capital, tende a impor uma forte especialização da produção, o que implica igualmente na especialização do espaço regional. Isto, porém, está ligado a interesses distantes, tornando muitas vezes a sociedade regional estranha ao seu espaço e à sua terra, pois foi transformada meramente em fábrica e "a própria região fica alienada, já que não produz mais para servir à necessidades reais daqueles que a habitam" (SANTOS, 2009, p. 29).

Observa-se a construção de um poder global multifacetado que expressa estrategicamente as práticas políticas e os interesses de grandes grupos econômicos e das organizações multilaterais. Esses novos atores globais, diante da crescente ampliação das relações econômicas, mediadas por novos sistemas técnicos e informacionais, impõem novas práticas e ações de controle de forma seletiva em diversas escalas espaciais (local, regional, nacional e global) para um maior aproveitamento de mercado, exploração de recursos e de mão de obra barata. Pode-se afirmar que presenciamos mudanças das práticas do poder material, as quais criam novas estratégias de desenvolvimento, inserindo os novos arranjos espaciais produtivos em um processo neoliberal de integração vertical regional.

As ZPEs, no contexto de um mercado globalizante, representam um projeto neoliberal de integração vertical regional. Ao adotarem esse instrumento de política econômica como estratégia de desenvolvimento, os governos - sobretudo dos países subdesenvolvidos - abrem suas fronteiras, delimitando "áreas" ou espaços específicos cujo objetivo é estabelecer condições ou uma atmosfera de "livre comércio" assentada e/ou regida por normas e regras específicas (ONG, 2004, 2006).

30 Portanto, compreendemos que a expansão de ZPEs no mundo tem se constituído enquanto uma nova estratégia de desenvolvimento contida em um aparato políticodiscursivo de inserção de certos arranjos espaciais produtivos (região/localidade) nas redes de produção globais. Dessa forma, prosseguimos para uma breve discussão abordando sua definição e estratégia global de expansão.

\section{As Zonas de Processamento de Exportações (ZPEs) no mundo: definição e estratégia global de expansão}

A expansão das ZPEs no mundo ocorre em um contexto de mudanças na ordem política e econômica, tendo como pano de fundo o processo de reestruturação econômica e a ascensão da globalização neoliberal. Como consequência, Sarti e Hiratuka (2010) argumentam que ocorrem mudanças estratégicas na reorganização da produção e nas 
formas de organização e concorrência das grandes corporações, repercutindo na divisão internacional do trabalho.

Todavia, observam-se também implicações na política nacional de desenvolvimento dos países, sobretudo aos chamados países subdesenvolvidos. Desse modo, os países buscando fórmula ou nova estratégia de desenvolvimento, com finalidade de se integrarem na fragmentação da produção, passam a adotar as ZPEs como instrumento de política econômica industrial.

33 A utilização das ZPEs como modelo político-econômico não é recente. Na Antiguidade, diversas cidades do mediterrâneo utilizavam esse modelo, que funcionava como portos livres cujo objetivo era estimular as trocas comerciais.

A partir do século XVIII, tal modelo já estabelecia as principais rotas comerciais do mundo com funções de transbordo de mercadorias, armazenamento e exportação, sem formalidades alfandegárias. No decorrer do ano de 1934, as ZPEs foram implantadas nos Estados Unidos nos moldes contemporâneos por meio de uma adaptação da noção de Zona de Livre Comércio (ZLC). Assim, não era necessário que a área estivesse especificamente localizada em um ponto determinado do território, como porto, aeroporto etc. (WONG E CHU, 1984; EGLER, 1991 e SILVA, 1993). A partir dos anos $1960 \mathrm{e}$ 1970, ocorre sua expansão no mundo, como pode ser observada na Tabela 1.

Tabela 1. Evolução das ZPEs no mundo.

\begin{tabular}{r|cccccc}
\multicolumn{2}{c}{1975} & 1986 & 1995 & 1997 & 2002 & 2006 \\
\hline & & & & & & \\
\hline $\begin{array}{r}\text { Nímeros de Países } \\
\text { com ZPEs }\end{array}$ & 29 & 47 & 73 & 93 & 116 & 130 \\
$\begin{array}{r}\text { Números de ZPEs } \\
\text { Empregos }\end{array}$ & 79 & 176 & 500 & 845 & 3000 & 3500 \\
(milhóes) & - & - & - & 22.5 & 43 & 66 \\
China & - & - & - & 18 & 30 & 40
\end{tabular}

Fonte: Trade Union manual on Export Processing Zones (2014, p. 04).

Desse modo, em trinta anos, houve uma significativa expansão das ZPEs no mundo. Em 1975, existiam apenas 79 ZPEs em 29 países; no ano de 2006, o número de ZPEs atingiu a marca de 3.500 distribuídas em mais de 130 países (OCDE, 2007). Essa expansão ocorreu em diferentes partes do mundo, conforme se verifica no Mapa 1. 
Mapa 1. Distribuição das Zonas de Processamento de Exportações (ZPEs) por países (2008)

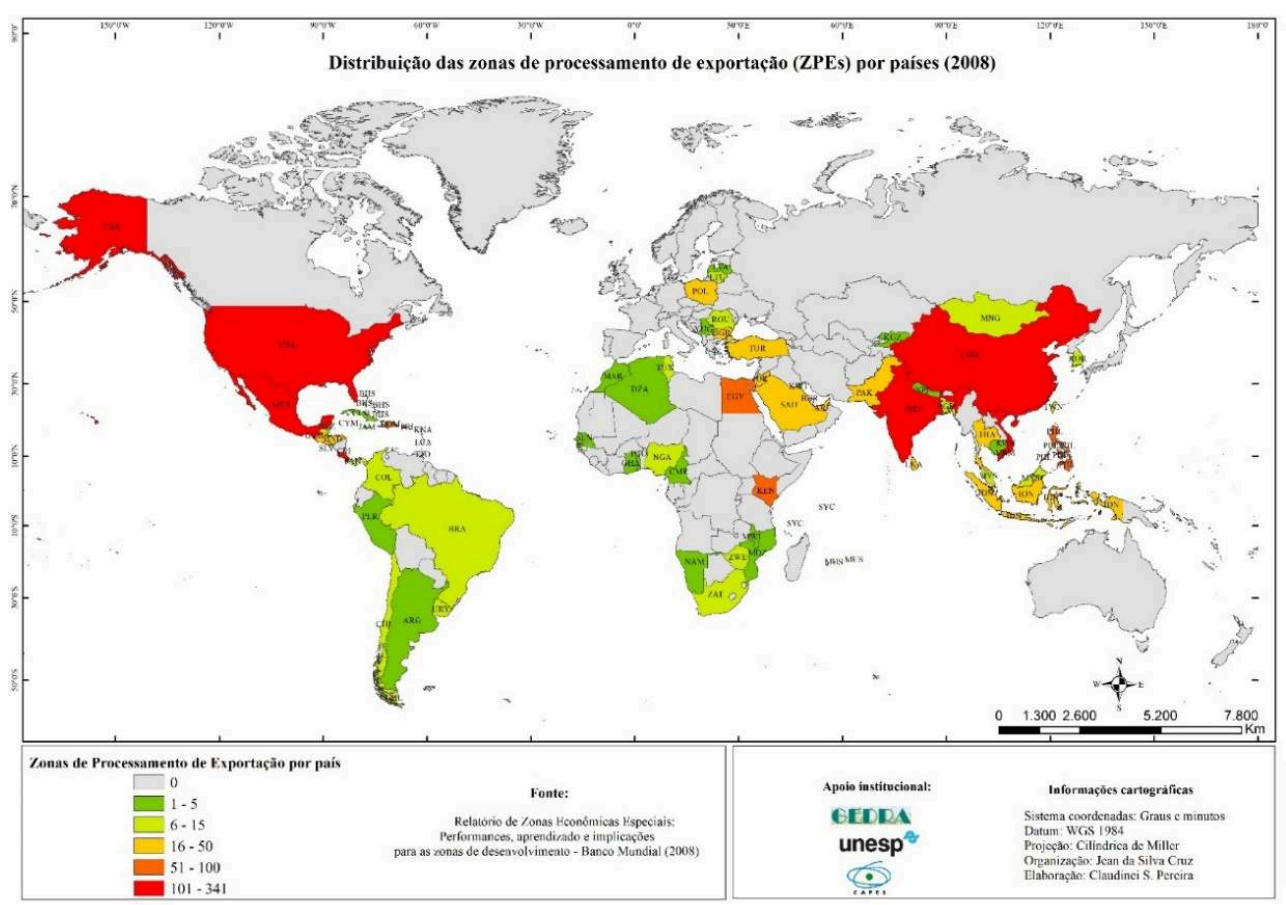

Fonte: Relatório Banco Mundial (2008)

Na Ásia, destacou-se a Índia, que implantou sua primeira ZPE em Kandla em 1965, seguida da China, mais especificamente Kaohsiung, também no ano de 1965; em 1970, ocorreu a implantação da primeira ZPE na República da Coreia e, em 1972, em Bataan, nas Felipinas. No continente Africano, as primeiras ZPEs foram implantadas na década de 1970 no Senegal, Libéria e Gana. No caso da América Latina e do Caribe, as primeiras ZPEs se estabeleceram a partir dos anos 1970, por exemplo, em Barranquilla (Colômbia), Puerto Cortés (Honduras), San Bartolo (El Salvador), Santa Rosa/El Roblie (Costa Rica).

Conforme relatório publicado em 2008 pela Foreign Investment Advisory Service (FIAS), o continente asiático é responsável por empregar $85 \%$ de todos os trabalhadores das ZPEs no mundo. O destaque é para a China, onde há uma estimativa de 40 milhões de empregados. Na Indonésia, estima-se um total de 6 milhões; em Bangladesh, 3,5 milhões; nas Filipinas, 1,1 milhão; na Malásia e Tailândia, 500.000; no Japão, cerca de 200.000; no Camboja, 200.000; e no Sri Lanka, mais 160.000 .

Cabe destacar que a expansão das ZPEs e a sua concentração no leste asiático (Figura 1) se inicia pelo movimento de industrialização no final da Segunda Guerra Mundial. Essa estratégia estava ancorada na promoção de um ritmo acelerado de crescimento econômico através da promoção industrial ligada à substituição de importações (WONG e CHU, 1984). 
Figura 1. Concentração de ZPEs por região

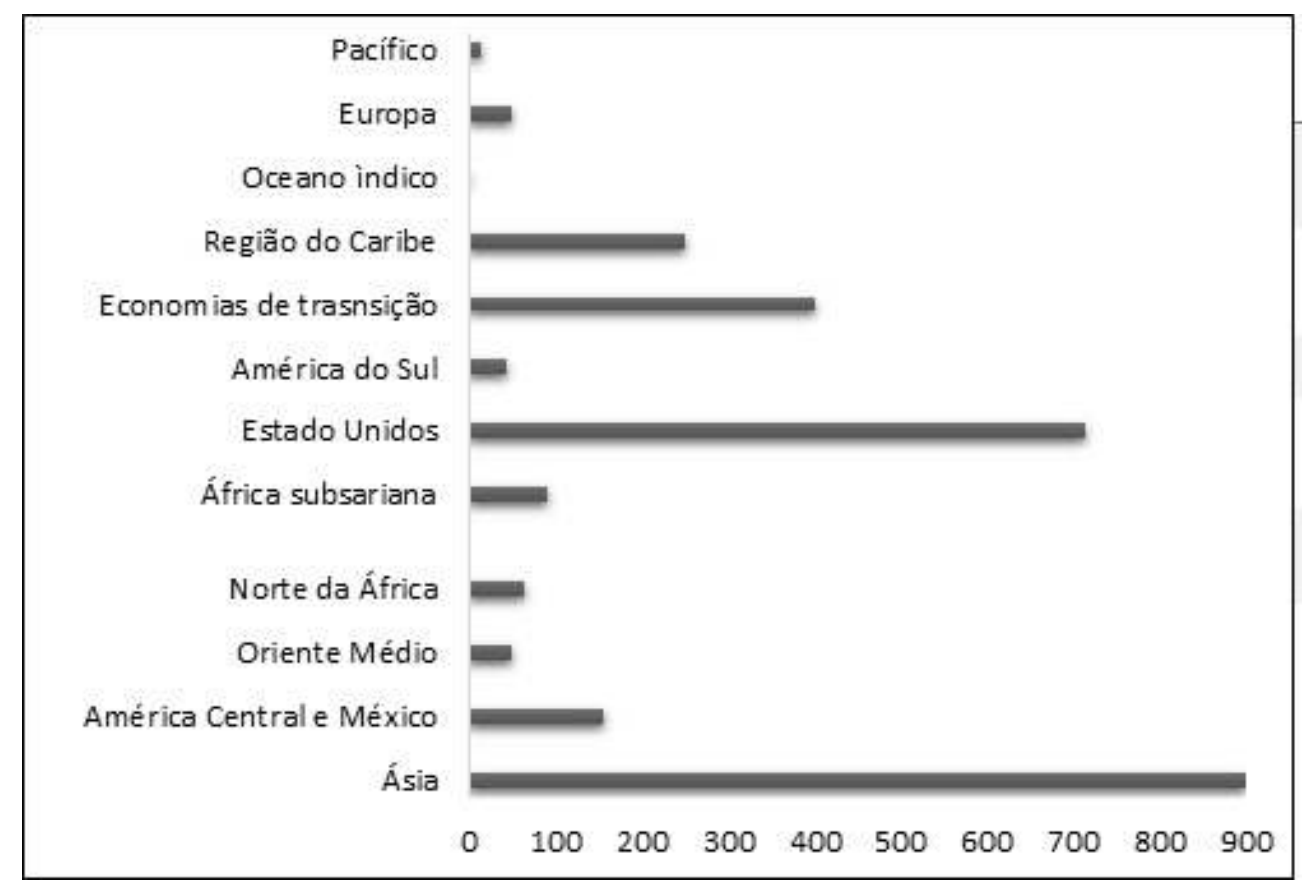

Fonte: Banco Mundial (2008)

Esse processo, por sua vez, marca o período de transferência das atividades de montagem padronizadas para o exterior, em virtude de necessitarem de grande quantidade de mão de obra de baixa qualificação - daí sua expansão ou implantação em zonas fronteiriças como no México, as chamadas "maquiladoras". No caso específico da China, a partir da década de 1970, foi adotada uma estratégia de desenvolvimento através de ZPEs em várias regiões do país, conforme destaca Egler (1991).

Esse período, de acordo com Lan (2017), retrata o processo de descentralização industrial que se materializava tanto em escala nacional, por meio de políticas públicas territoriais voltadas à periferia interna, quanto em escala internacional, para os países subdesenvolvidos ou em vias de desenvolvimento. Essa estratégia de deslocamentos tem por finalidade explorar matérias-primas e força de trabalho, assim, as empresas se deslocam visando buscar mão de obra não especializada e barata nos países subdesenvolvidos, enquanto que as atividades da área de pesquisa e desenvolvimento das empresas e o trabalho qualificado são mantidos nos países industrializados.

41 Para Sarti e Hiratuka (2010), o deslocamento da atividade industrial em direção aos países subdesenvolvidos, com destaque para o leste asiático, alavancada pela China, que emerge como grande produtor mundial de manufaturas, e em menor proporção para a América Latina, ocorreu em meio a essa onda de "deslocamento" e/ou descentralização, porém com desempenhos diferenciados entre os países.

o que se verifica diante desse movimento é a acentuada concentração nas principais cadeias industriais. Sarti e Hiratuka (2010) apontam para um padrão assimétrico de inserção produtiva e comercial, mostrando uma concentração da atividade industrial nos países da Tríade, constituída pelos Estados Unidos da América (EUA), Europa e Japão, sendo que o deslocamento para os países subdesenvolvidos, como o Brasil e a Coréia do Sul, ocorreu apenas de forma marginal. Isto porque essa forma de inserção 
diferencial no processo decorreu a partir das estratégias nacionais de cada país, refletindo em diferentes padrões de desenvolvimento industrial.

A expansão das ZPEs corresponde a uma das facetas do processo de internacionalização do capital e de sua valorização, apropriando-se do conjunto das regiões do mundo onde há recursos ou mercados (CHESNAIS, 1996). Para o mesmo autor, esse processo apresentava dois movimentos distintos, os quais, por sua vez, permitiram remover os entraves que impediam as grandes empresas de se expandirem à vontade para explorarem os recursos econômicos, humanos e naturais conforme suas conveniências.

$\mathrm{O}$ primeiro movimento correspondia à mais longa fase de acumulação do capital. $\mathrm{O}$ segundo estava relacionado às políticas de liberalização, de privatização, de desregulamentação e de desmoronamento de conquistas sociais. No entanto, essas estratégias de expansão representam uma ação seletiva em nível mundial, pois, de um lado, discursivamente tal estratégia é global, porém reservando um processo integrador e, ao mesmo tempo, é excludente. Na visão do autor, "há uma polarização internacional, aprofundando brutalmente a distância entre os países situados no âmago do oligopólio mundial e os países da periferia" (CHESNAIS, 1996, p. 37).

Como uma face específica do processo de internacionalização do capital e de sua valorização, as ZPEs são definidas pelos organismos internacionais, tais como o Banco Mundial, a United Nations Industrial Development Organization (UNIDO) e a United Nations Conference on Trade and Development (UNCTAD), como uma parcela do território estritamente bem definida (zonas industriais cercadas entre 10 e 300 hectares) cujo objetivo é atrair indústrias orientadas para a exportação e, dentro dessas áreas e/ou zonas, passam a coexistir empresas estrangeiras e nacionais.

Em relação à gestão desses espaços, estes podem ser administrados tanto pela iniciativa privada quanto conjuntamente com os governos. Contudo, atualmente, $61 \%$ das ZPEs no mundo são administradas pela iniciativa privada (Figura 2) por se considerar uma forma menos dispendiosa tanto para desenvolver e operar quanto para produzir melhores resultados econômicos, segundo o Banco Mundial. 
Figura 2. Localização das ZPEs públicas e privadas por região

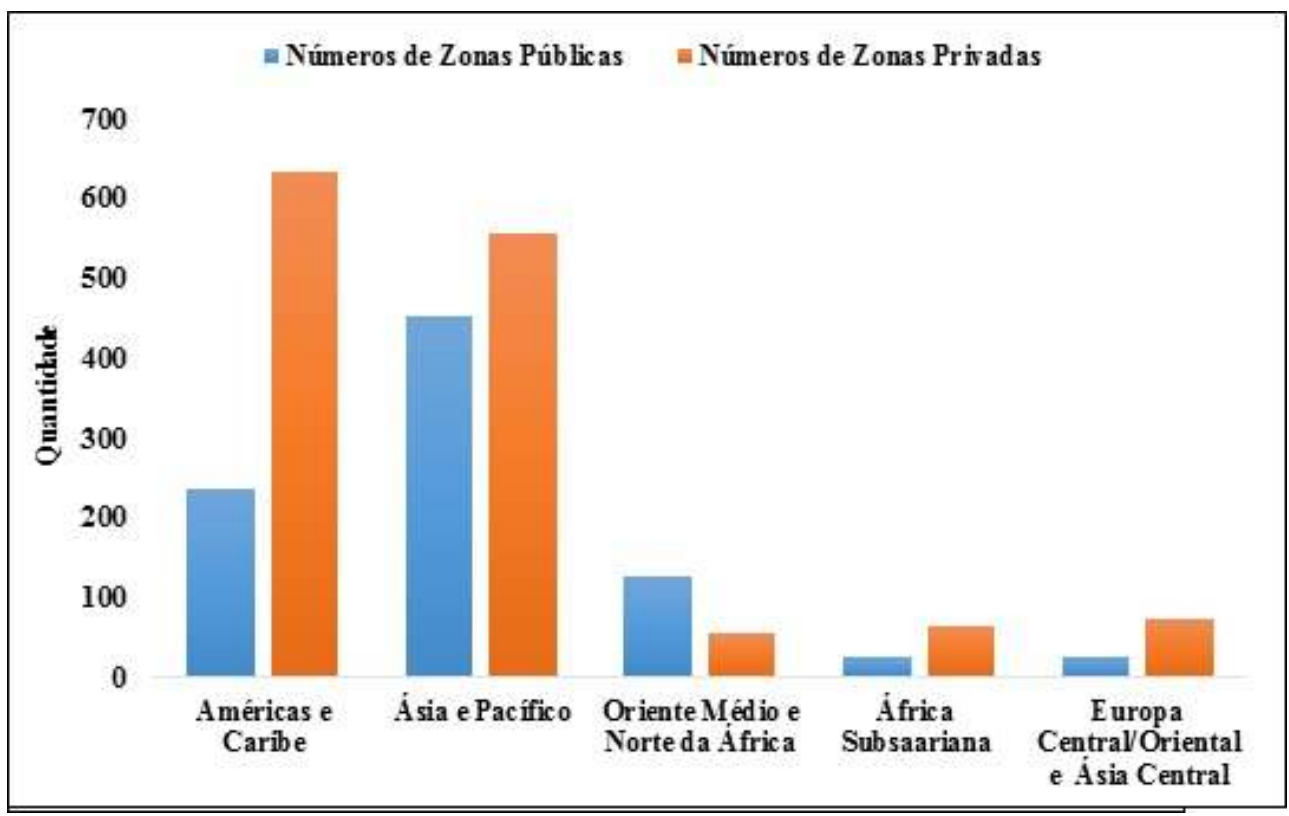

Fonte: Banco Mundial (2008).

Sobre o aspecto de norma e regra, é específica e/ou diferenciada. Assim, com interesse em atrair investidores, segue-se uma tendência de flexibilização na legislação, estabelecendo incentivos especiais - sobretudo fiscais, cambiais e trabalhistas - e acesso à infraestrutura, que passa a ser de responsabilidade dos governos. Embora apresentem mudanças de acordo com os países, os principais tipos de atividades direcionadas, nessas zonas, estão voltados à setores tradicionais, tais como produtos têxteis e vestuários. Algumas novas zonas passaram a se especializar em produtos eletrônicos, químicos e em serviços ligados à Tecnologia da Informação (TI), conforme se verifica na Tabela 2.

Tabela 2. Números de ZPEs para serviços por regiões

\begin{tabular}{cc}
\hline REGIÃO & $\mathrm{N}^{\circ}$ \\
\hline União Europeia & 5 \\
\hline África & 20 \\
\hline América Latina e Caribe & 26 \\
\hline Ásia e Pacifico & 26 \\
\hline Europa Central e Oriental & 13 \\
\hline Total & 90 \\
\hline
\end{tabular}

Fonte: UNCTAD Investment Brief (2004).

48 As ZPEs voltadas ao setor de serviços se concentram nos países subdesenvolvidos. Como forma de atrair investimentos estrangeiros para esse setor, os países disponibilizam telecomunicação de alta qualidade, infraestrutura de suporte de tecnologia, variedades 
de incentivos (como 100\% de isenção de tarifas de importação), isenção de impostos, repatriação integral de lucros e despacho aduaneiro.

O modelo indiano de ZPEs tem sido preconizado como o mais bem sucedido, conforme aponta a UNCTAD (2004). Relacionado ao offshoring de serviços, os IEDs têm sido atraídos para parques tecnológicos. Essas zonas foram criadas em $1990 \mathrm{em}$ Bagalore, Pune e Bhubaneshwar, sendo que em 2003 havia 39 zonas com cerca de 7.000 estabelecimentos cadastrados, os quais eram responsáveis por $80 \%$ das exportações de software do país. As Ilhas Maurício também passaram a especializar suas ZPEs para atrair IEDs em serviços empresariais. A África francófona visa atrair IEDs para ZPEs centradas no projeto "Cyber City", para o investimento em serviços de call center e serviços de back-office. Na Jamaica, a ZPE constitui parque corporativo conectado com fibras ópticas e tecnologia de satélite, atraindo IEDs voltados aos serviços de offshore.

Em suma, a última metade do século XX foi significativa para a expansão desse modelo de política econômica industrial em algumas regiões do mundo. Entretanto, essa expansão global não ocorreu "às cegas" e sim através de um tipo específico de projeto e instrumento de política econômica industrial no âmbito global.

51 As ZPEs foram fortemente propaladas por instituições como o Banco Mundial, a UNIDO e a UNCTAD. A principal ideia-força preconizada por essas instituições para o incentivo e a difusão de ZPEs como ferramenta política econômica industrial está sustentada no discurso de que o uso dessa ferramenta traria a solução para os problemas socioeconômicos dos países subdesenvolvidos em virtude de alguns benefícios, como mostra a Figura 3.

Figura 3. Benefícios de uma ZPE

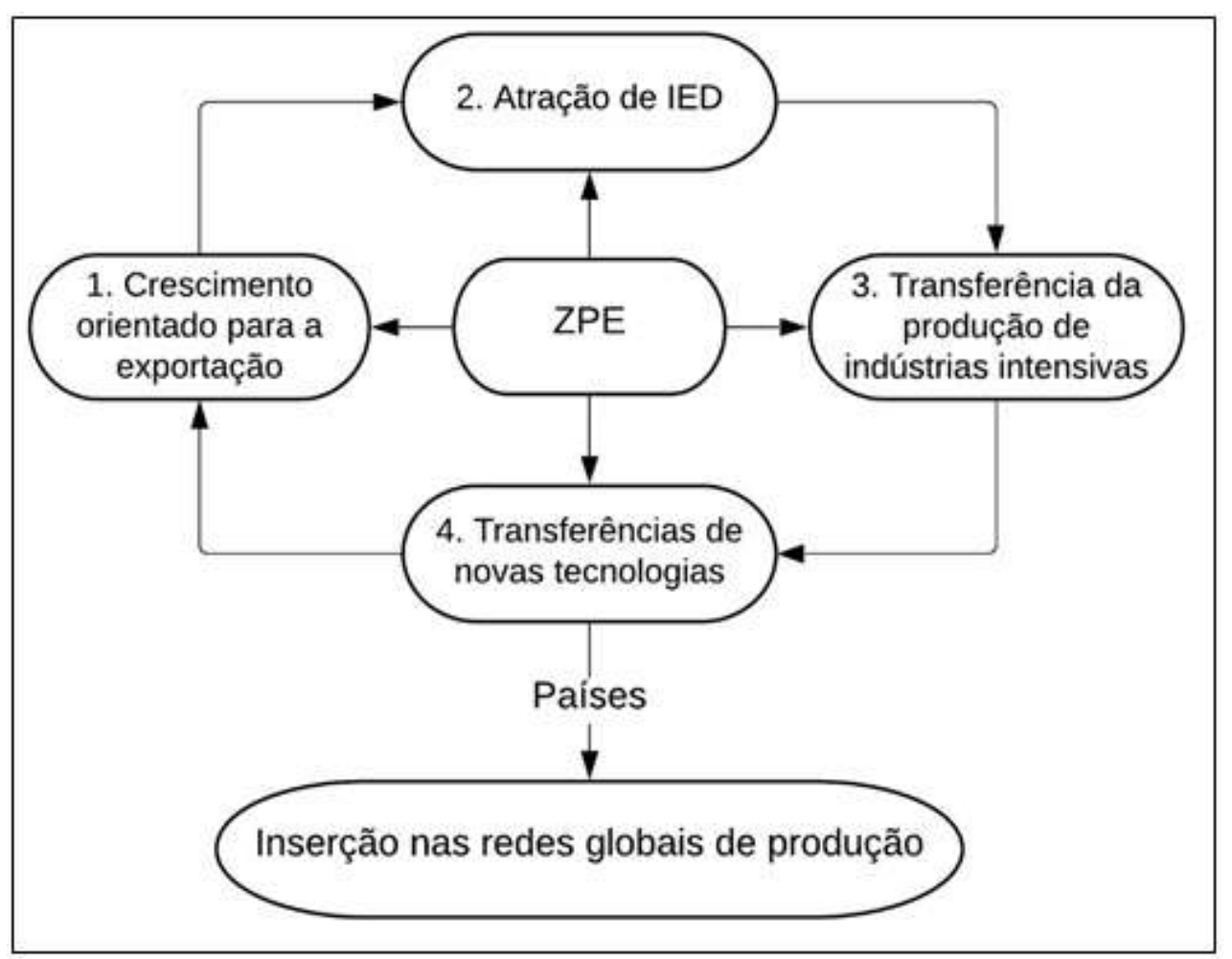

Fonte: OCDE (2007). 
O principal atributo das ZPEs é o de promover o desenvolvimento industrial orientado para a exportação, ou seja, contribuem para a substituição de importações e, a partir daí, podem cooperar para o fortalecimento das políticas de crescimento de exportações devido ao deslocamento de indústrias intensivas em mão de obra provenientes dos países desenvolvidos.

Como benefício, os países subdesenvolvidos passam a atrair os chamados IEDs, contribuindo para a modernização e a difusão tecnológica. Em segundo, a adoção desse instrumento enquanto estratégia alternativa de desenvolvimento pelos governos vai favorecer a entrada de seus países de forma competitiva no circuito globalizado da produção e da troca, bem como a solução os seus problemas econômicos e sociais.

54 No relatório do Banco Mundial divulgado no ano de $1992^{6}$, em um contexto de plena abertura do comércio internacional, em seu prefácio, o Diretor de Política Setorial e Operacional do Departamento de Indústria e Energia, Anthony A. Churchill, ao fazer menção a ZPEs, deixa claro as intenções da instituição e de seu apoio à elaboração de instrumentos políticos e administrativos, ressaltando, ainda, a necessidade da própria instituição em contribuir para a realização de melhorias nos marcos de políticas regulatórias para fortalecer o comércio cada vez mais orientado e/ou voltado para o exterior, bem como a necessidade da busca de ampliação da competitividade internacional das indústrias.

55 As ZPEs, portanto, teriam papel-chave nessa nova dinâmica de internacionalização. Nesse caso, os países subdesenvolvidos, salienta Churchill, para poder ampliar sua participação nessa nova ordem econômica, poderiam se utilizar desse modelo de política econômica como uma ferramenta para "superar sua incapacidade de gerar resposta externa e fornecer emprego imediato, bem como ganhos em divisas estrangeiras mediante ao Investimento Estrangeiro Direto" (p.5).

56 Para maior eficiência em seu funcionamento, a orientação para os governos que adotam esse instrumento é de que seja criado um bom ambiente de negócios, ou seja, devem proporcionar condições favoráveis indispensáveis, como um ambiente de cooperação com o setor privado. Nessa relação de parceria pública/privada, devem buscar acordos especiais para garantir a recuperação total de custos (custo de desenvolvimento, incluindo aluguéis de terra, custos operacionais), pacote de incentivos (isenção de impostos e a instituição de leis trabalhistas mais "flexíveis"), uma política exclusivamente orientada para o exterior e uma gestão eficiente.

Desse modo, como um instrumento estratégico de política econômica, as ZPEs passariam a assumir uma espécie de "força centrípeta" que, a partir de certos pacotes de incentivos tanto para as empresas estrangeiras quanto para as nacionais, permitirá criar um ambiente regulatório estritamente favorável de negócios, estimulando os países subdesenvolvidos a participarem na exportação de manufaturados para as economias mais avançadas com um mínimo de burocracia.

58 Por isso, as razões do projeto de expansão das ZPEs são tão fortemente propaladas por essas instituições. Dissemina-se o discurso de que, a partir de um conjunto de benefícios, como ganhos em divisas, oferta de empregos, melhoria na renda, aprendizado por parte das empresas locais devido a sua aproximação com empresas estrangeiras, treinamento e agregação de habilidades (know-how) pelos trabalhadores locais empregados, a ZPE se constituiria em um sistema "mágico" (nos termos 
difundidos pelo relatório), um caminho mais fácil para os países importarem e exportarem.

Partindo-se desses pressupostos, dois pontos merecem atenção. 0 primeiro se refere à postura ideológica centrada na necessidade da abertura e/ou internacionalização econômica via ampliação do comércio internacional e à forma com que os chamados países subdesenvolvidos participariam dessa nova estratégia de inserção por igual no mercado mundial com os demais países em troca de abrirem suas fronteiras criando "espaços de exceção" política e econômica para estimular um ambiente de "livre comércio". O segundo ponto a ser destacado é que esse instrumento pode ser utilizado e/ou orientado conforme as políticas nacionais de cada país, como uma ferramenta estratégica de desenvolvimento regional via atração de investimentos industriais.

\section{ZPE: Um Projeto Neoliberal de Integração Vertical Regional}

60 A expansão das ZPEs para diferentes partes do mundo está atrelada às mudanças no cenário macroeconômico internacional, isto é, na crescente internacionalização das trocas e do comércio que ocorrem de forma imbricada ao processo de globalização neoliberal, propalada enquanto instrumento de política econômica industrial que induz uma nova estratégia de desenvolvimento.

61 Todavia, essa "nova" estratégia representa, por um lado, novos espaços de direção e atração de fluxos de investimentos, condicionada sob as novas formas de gestão da cadeia de produção e de valor promovida pelas empresas transnacionais para além de suas fronteiras nacionais, na busca de ganhos mais lucrativos. Por outro lado, induz novas posturas aos Estados nacionais, onde suas decisões de política de desenvolvimento passam a ser orientadas pela força do mercado e, assim, abrem suas fronteiras, delimitando "áreas" ou espaços de exceção política e econômica (ONG, 2004, 2006).

62 Não obstante, quando se analisa as ZPEs enquanto novos espaços de direção e atração de fluxos de investimentos, sobretudo os chamados IED ${ }^{7}$, esse tipo de investimento exerceria um papel-chave no processo de intercâmbio e/ou interligação entre os países, segundo o relatório do Banco Mundial.

As ZPEs são há muito tempo uma ferramenta política popular para atrair IED orientado para a exportação. De fato, os maiores "vencedores" na competitividade das exportações durante as últimas duas décadas estabeleceram algum tipo de ZPE. As ZPEs são muitas vezes responsáveis por uma grande parte das exportações de manufaturados de países em desenvolvimento (UNCTAD, 2004, p. 01).

63 As ZPEs, enquanto espaços criados para gerar oportunidades de negócio, como sustentado, constituiriam uma ótima ferramenta para a direção e o conteúdo dos fluxos de investimento por oferecer pacotes atraentes a investidores ligados ao desenvolvimento de indústrias de exportação. Os IEDs seriam, portanto, uma importante fonte externa de financiamento, dando apoio ao desenvolvimento da economia dos países subdesenvolvidos. Dessa maneira, não atuariam apenas em fonte direta de câmbio, mas teriam significância no preenchimento de lacunas referentes às novas tecnologias, gestão de know-how e inteligência de mercado. 
O que podemos inferir é que as ZPEs são apresentadas como um modelo alternativo de política de desenvolvimento e de superação do atraso econômico por ser uma ferramenta de atração de investimentos. A estratégia pode ser adotada pelos governos como uma política alternativa de desenvolvimento nacional e como uma saída para os seus países se inserirem, com certo "sucesso competitivo", no mercado estrangeiro e em redes globais de produção.

Estas constatações nos permitem desvelar o papel discursivo dos IEDs que, no fundo, apresentam a face geográfica da mundialização econômica. As obras de Chesnais (1996) e Dicken $(2010)^{8}$ nos permitem depreender as entrelinhas e o jogo de interesses existente por de trás dessa estratégia de internacionalização dos intercâmbios e/ou da interligação crescente das fronteiras nacionais promovidas pelos IEDs.

Chesnais (1996) chama atenção ao fato de que os países subdesenvolvidos e o lugar que eles ocupam no sistema mundial de intercâmbio não decorreram de um resultado natural. Desde o final do século XIX, a inserção e as especializações comerciais de vários países ou regiões do mundo foram realizadas de forma seletiva e gradativamente determinadas pelos IEDs. Igualmente, o autor afirma que os países subdesenvolvidos foram alvos dessas estratégias de intercâmbio, o que fora determinante para suas especializações como produtores e exportadores de matérias-primas básicas, favorecendo a criação de relações moldadas pelo capital e de dominação pelos países capitalistas centrais.

Depois da Segunda Guerra Mundial, os IEDs apresentaram considerável crescimento e difusão. Dicken (2010) salienta que a expressiva e crescente interligação foi resultado do aumento do comércio mundial e do crescimento das atividades das Empresas Transnacionais (ETNs), que passaram a direcionar seus investimentos diretos através das fronteiras nacionais para obter estrategicamente novas formas de controle e o estabelecimento de filiais ou subsidiárias em outros países. Dicken (2010, p. 57) mostra que:

Durante os anos 1970 e na primeira metade dos anos 1980, as linhas de tendência de IED e exportações andavam mais ou menos lado a lado. Mais adiante, 1985 a 1990, a taxa de crescimento de IED e das exportações e o PIB divergiram rapidamente. Entre 1986 a 1990, as saídas de IED aumentaram a uma taxa média anual de 25\%, e o saldo acumulado de IED, a uma taxa anual de $18 \%$, em comparação com uma taxa de crescimento de exportações mundiais de 12,7\% (DICKEN, 2010, p. 57).

8 A década de 1980 constituiu um marco significativo do crescimento de IED no mundo. No entanto, conforme ressalta Chesnais (1990), nessa década, foram intensificadas as interdependências entre os países, o que significa também um marco no componente estratégico na decisão de investimento das ETNs. A intensa penetração desses tipos de investimentos nos países contribuiu para sugarem as tecnologias locais. Com efeito, constituiu-se um mecanismo de apropriação, centralização de ativos ou riquezas por parte dos agentes econômicos, que intensificou riscos e oportunidades para as empresas domésticas nas economias dos países subdesenvolvidos (CHESNAIS, 1990; SARTI; HIRATUKA, 2010).

No receituário apresentado aos governos, as ZPEs então assumiriam importância quanto à crescente interligação via fluxo de IED, cumprindo um papel-chave na atração de investimentos. Desse modo, impulsionariam suas economias, gerando o encadeamento generalizado, mais precisamente, na criação de empregos, na elevação do padrão de vida da população, no setor exportador e nos ganhos em divisas de moeda 
estrangeira. Os IEDs seriam, nesse caso, um componente ideal para as políticas de desenvolvimento e a dinâmica econômica geral, como destaca o Banco Mundial.

Embora tenha o discurso da inserção de países com certa competitividade no processo de produção e troca no cenário internacional, os dados dos fluxos de IED para as ZPEs nos países subdesenvolvidos mostram, a partir das origens ou principais fontes de IED e dos principais mercados de exportações dos países ou regiões, que são alvos do modelo de ZPEs - uma inserção de interdependência com alto grau de hierarquização e especialização.

71 Contudo, com o aprofundamento do processo de internacionalização produtiva, como salienta Hiratuka e Sarti (2011), houve certa diversificação na origem e destinação de recursos - as principais origens e/ou fontes dos IEDs são provenientes dos principais países capitalistas centrais. Segundo Dickens (2010), 90\% do estoque de IED são oriundos de apenas 15 países, com a predominância dos Estados Unidos e Reino Unido, sendo que os dois, conjuntamente, respondem por um terço do total mundial (DICKEN, 2010).

Em relação à predominância das origens e/ou das fontes de IED em ZPEs quando em análise por região, verifica-se que há alternância entre os principais países. As principais fontes de IED nas Américas e no Caribe são os EUA (30,77\%) e o Japão (12,31\%), seguidos da Coreia do Sul (10,77\%). Na Ásia, a predominância das fontes de IED são o Japão (22\%), os EUA (14\%) e a China (12\%). No Oriente Médio, Norte da África, Europa Central, Ásia Central e África Subsaariana, as fontes predominantes são a União Europeia, Estados Unidos e Reino Unido.

Em contrapartida, as regiões alvo do movimento de IED passam a ter certa interdependência em relação ao mercado de exportação, isto é, os principais mercados de exportação são predominantemente os países centrais. Para o continente americano e o Caribe, o principal mercado para exportação são os EUA, com $48,72 \%$, sendo que o Mercosul corresponde a apenas $12,82 \%$.

Os principais mercados dos produtos asiáticos são os EUA, com participação de 35,90\%, e o Japão, com 23,08\%. Os principais mercados de exportação da Europa Central/ Oriental e Ásia Central são a União Europeia com 38,46\%, e a Rússia, com 30,77\%. O Oriente Médio, Norte da África, juntamente com a região da África Subsaariana, têm como principal mercado a União Europeia, o Reino Unido e o próprio mercado regional.

Essas relações da inserção de interdependência evidenciam que as ZPEs criam alto grau de hierarquização e especialização geográfica no âmbito da produção e das trocas comerciais. Os IEDs, como já apontavam Chesnais (1996), apenas reforçam esse papel, isto é, o movimento de IEDs para os países subdesenvolvidos surge nesse novo cenário enquanto componente-chave de especialização geográfica de produção, como se verifica no Quadro 1. 
Quadro 1 - ZPEs: especialização geográfica de produção por regiões

\begin{tabular}{|c|c|}
\hline ZPEs por regiões & Principais setores \\
\hline Américas e Caribe & $\begin{array}{c}\text { Artigos esportivos, Automobilisticos, Armazenagem } \\
\text { e montagem de equipamentos elétricos e eletrônicos, } \\
\text { Armazém, Call Centers, Componentes automotivos, } \\
\text { Comércio de eletrônicos, Farmacêutico, Financeiro, } \\
\text { Logistica, Petrolifero, Petroquimica, Processamento } \\
\text { agropecuário, Semicondutores, Serviços, } \\
\text { Silvicultura, Suplementos médicos, Têxtil, } \\
\text { Transbordo e Vestuário. }\end{array}$ \\
\hline Ásia e Pacífico & $\begin{array}{l}\text { Alta tecnologia, Biotecnologia, Couros, Calçados, } \\
\text { Eletrônicos, Eletrodomésticos, Elétricos, Impressão, } \\
\text { Joias, Luvas, Malas, Metalurgia, Maquinaria } \\
\text { Elétrica, Processamento de Alimentos, Produtos } \\
\text { Farmacêuticos, Produtos Quimicos, Software, } \\
\text { Serviços Financeiros, Têxtil e Vestuário. }\end{array}$ \\
\hline Oriente Médio e Norte da Africa & $\begin{array}{c}\text { Alimentos, Agricultura, Calçados, Couros, Elétricos, } \\
\text { Embalagens de Couro, Finanças, Indústria de Vidro e } \\
\text { Elétrica, Logistica, Manufatur as, Mineração, Pesca, } \\
\text { Petroquimica, Processamento de Alimentos, } \\
\text { Serviços, Turismo e Vestuário. }\end{array}$ \\
\hline $\begin{array}{c}\text { Europa Central/Oriental e Ásia } \\
\text { Central }\end{array}$ & $\begin{array}{l}\text { Armazém, Acessórios, Automóveis, Componentes } \\
\text { Automotivos, Elétricos, Máquinas, Materiais de } \\
\text { Construção, Maquinaria Elétrica, Negócios, Peças de } \\
\text { Mobiliário, Processamento de Alimentos, Produtos } \\
\text { Petroliferos e Vestuário. }\end{array}$ \\
\hline Africa Subsaariana & $\begin{array}{l}\text { Aluminio, Agro-processamento, Automotivo, Call } \\
\text { Centers, Couro, Fundição de Aluminio, Gás, } \\
\text { Impressão, Madeira, Metalurgia, Perucas, } \\
\text { Processamento de Alimentos, Processamento de } \\
\text { Madeiras, Peças Automotivas, Petróleo, Têxtil e } \\
\text { Vestuário. }\end{array}$ \\
\hline
\end{tabular}

Fonte: FIAS (2008). Organizado pelo autor. regiões produtivas especializadas, em um processo neoliberal de integração vertical regional articulada em torno da nova divisão espacial e internacional do trabalho, na qual as diferentes fases do processo de produção são atribuídas no espaço de modo diferenciado. Nas regiões centrais (inclusive as regiões dos países subdesenvolvidos), são instaladas atividades de nível tecnológico mais elevado, de qualificação e funções direcionais, enquanto que nas periferias são instaladas atividades mais simples que requerem menor qualificação profissional (BENKO, 2002).

Cabe destacar que o processo de mudança de direcionamento do fluxo de IED para essas regiões ocorreu de modo gradativo e seletivo e provocou a concentração da produção em algumas regiões. Exemplos disso são as regiões da Ásia e do Pacífico, sobretudo o leste asiático, liderado pela China, com destaque para a manufatura, a internacionalização de serviços e administração na Índia e para atividades ligadas à agricultura moderna na América Latina, principalmente o Brasil (DICKEN, 2010).

As entradas ou direcionamento dos fluxos de IED em países subdesenvolvidos, em um exame mais refinado e tomando emprestado o termo empregado por Sarti e Hiratuka (2010), é um movimento de inserção assimétrico. Em outras palavras, mesmo com a intensidade do processo de internacionalização nos últimos 30 anos, que promoveu forte deslocamento do processo produtivo e o redirecionamento dos fluxos globais de produção, de investimento e de comércio exterior, sobretudo dos fluxos de investimento direto no exterior, houve o fortalecimento de uma conformação das redes de produção em nível internacional de forma hierarquizada e seletiva. 
Isso mostra que os dados estatísticos referentes aos fluxos são apenas aparentes. As razões desse movimento aparente decorrem da intensificação da concorrência entre as grandes corporações que passaram a reorganizar a cadeia de valor e as atividades produtivas ao redor do mundo, provocando uma dispersão geográfica (cadeia de produção e comercialização), ao mesmo tempo em que ocorre uma especialização crescente e, em segundo, repercutindo em diferentes formas de inserção dos países subdesenvolvidos, tanto comercial quanto produtiva (SARTI; HIRATUKA, 2010).

Entre 2015 e 2019, os influxos de IED mostraram que o processo de intercâmbio ocorreu de forma predominante entre os países da tríade constituída pela América do Norte, Europa e Ásia, conforme se verifica na Tabela 3.

Tabela 3. Influxos de IED por grupo de economias em regiões de 2015 a 2019 (em bilhões de dólares)

\begin{tabular}{|c|c|c|c|c|c|}
\hline Grupo de economias/regiões & 2015 & 2016 & 2017 & 2018 & 2019 \\
\hline Mundo & 1921 & 1700 & 1430 & 1495 & 1540 \\
\hline Economias desenvolvidas & 1141 & 1133 & 950 & 761 & 800 \\
\hline Europa & 595 & 565 & 570 & 364 & 429 \\
\hline América do Norte & 595 & 494 & 304 & 297 & 297 \\
\hline Economias em desenvolvimento & 744 & 670 & 701 & 699 & 685 \\
\hline África & 57 & 53 & 42 & 51 & 45 \\
\hline Ásia & 516 & 475 & 502 & 499 & 474 \\
\hline América Latina e Caribe & 169 & 140 & 156 & 149 & 164 \\
\hline Economias em transição & 36 & 64 & 50 & 35 & 55 \\
\hline
\end{tabular}

Fonte: UNCTAD (2018; 2020).

81 Segundo Dicken (2010), a metade de toda entrada de IED está concentrada em cinco países hospedeiros, sendo que apenas a China e Hong Kong concentram quase um terço do total.

$\mathrm{Na}$ realidade, embora os países em desenvolvimento, como um grupo, tenham aumentado sua participação nas exportações globais de entrada de investimento direto externo, essa participação permanece muito limitada. A maioria dos IEDs mundiais movimenta-se entre os países desenvolvidos com padrões complexos de investimento cruzado (DICKEN, 2010, p. 59).

82 A participação dos países subdesenvolvidos no movimento de IED é assimétrica, limitada e hierárquica, resultando numa integração parcial no sistema, haja vista que a maioria dos IEDs mundiais se movimenta entre os países desenvolvidos, como destacado na Tabela 3. Além da participação assimétrica, limitada e hierárquica, o influxo de IED segue tendências cíclicas e não deixa de estar ligado às respostas positivas do mercado e às ações e/ou decisões políticas no âmbito global.

83 Os dados do relatório UNCTAD (2020) mostram que, o fluxo global de IED apresentou um forte declínio (apesar dos fluxos globais de IED terem apresentado um aumento de $3 \%$ em 2019) de $42 \%$, em um dos mais baixos níveis desde os anos de 1990, com tendências de um ciclo negativo face a conjuntura da pandemia de Covid-19. Entre os 
grupos econômicos, os países desenvolvidos apresentaram queda no fluxo de IED: na Europa, entre $30 \%$ e $45 \%$ e na América do Norte, com queda entre $20 \%$ e $35 \%$. O influxo de IED em direção à África registrou queda entre $20 \%$ e $40 \%$. Em direção à Ásia os fluxos foram seriamente afetados, no entanto, o sudeste asiático, liderado pela China apresentou um resultado positivo, em decorrência da dependência global em cadeias de suprimento que permitiram o crescimento do fluxo de IED. Já em relação à América e ao Caribe, o movimento de IED caiu pela metade em 2020 devido às incertezas da macroeconômicas e políticas.

Portanto, essas tendências de ciclo negativo sugerem uma contração de fluxo de IED entre $5 \%$ e $10 \%$ a mais em 2021. Logo, trazendo perspectivas de recuperação marcadas por tensões e incertezas no âmbito do mercado mundial. Tensões e incertezas em relação à duração da crise de saúde, eficácia das intervenções públicas para mitigar os efeitos econômicos da pandemia, bem como os riscos geopolíticos, as crescentes tensões comerciais e as mudanças nas políticas protecionistas. Todas essas variáveis podem resultar em impacto negativo sobre os fluxos de IED, haja vista que, como fonte externa de financiamento, os principais investidores buscam retornos lucrativos.

Diante desse cenário, as ZPEs, embora preconizadas como espaço de direção ou atração de fluxos de investimento, são assimétricas, limitadas e hierárquicas, integrando de modo parcial países ou regiões. Em outros termos, esses movimentos dependem das respostas positivas do mercado e das ações e/ou decisões políticas de investidores em busca de maiores lucros.

86 A estratégia de desenvolvimento por meio das ZPEs induz os Estados nacionais a uma nova postura, sendo adotadas práticas estatais flexíveis nas quais as decisões relacionadas às políticas de desenvolvimento passam a ser orientadas pela força do mercado, ou melhor, para o cálculo de mercado. Os governos criam espaços excepcionais com o intuito de aumentar a atração de investimentos estrangeiros e estimular as atividades econômicas, alinhando-se ao aparato discursivo da melhoria do bem-estar socioeconômico dos seus países.

Santos (2006) destaca que as normas e regras são criadas intencionalmente e esboçam a ação e o comportamento das organizações, sejam elas empresas, instituições públicas ou privadas subsumidas à lógica dos processos econômicos, sendo, assim, imprescindíveis para cumprir certas funções e para o ordenamento das coisas.

No caso aqui analisado, entendemos que a estratégia de desenvolvimento através de ZPEs impõe leis e regras excepcionais de mercado que forjam espaços de exceção política e econômica em um contexto neoliberal. Em sua estrutura de política básica, por exemplo, essa ideia é assegurada pelo princípio da extraterritorialidade, o qual:

Consiste num instrumento de política econômica em que o Estado diferencia certas áreas do território ao oferecer câmbio livre, incentivos fiscais e jurisdição própria às empresas que para lá se dirige, sem, contudo, reduzir o controle sobre o restante da economia nacional [...]. É como se criasse um território livre, globalizado, dentro do país, ligando-o à circulação internacional de capitais e mercados (SILVA, 1993, p. 57 , grifo nosso).

O princípio da extraterritorialidade, como descrito, aparece como um tipo bem definido de leis e regras excepcionais que regem esses "territórios livres", isto é, que buscam legitimar as trocas comerciais em pontos determinados no território, desse modo, garantindo, o câmbio livre, os incentivos fiscais, ou seja, as leis e regras de mercado que melhor convierem às empresas. Assim, validam certa liberdade para os negócios nesses 
“territórios livres", com o intuito de se forjarem conexões específicas à circulação e/ou integração internacional de capitais e mercados.

Os governos, na busca de atrair investimento externo e garantir acesso às novas tecnologias, passam a delimitar um território hospedeiro de capitais em valorização, com certa disponibilidade de energia, infraestrutura e mão de obra abundante. Assim, as ZPEs, sob esse princípio, atuam como uma espécie de enclave fabril onde a importação de equipamentos e matérias-primas é realizada sem incidência de tarifas, cobrança de impostos e onde as exportações são estimuladas e feitas sem restrições cambiais (EGLER, 1991).

91 Podemos afirmar que a extraterritorialidade assume um importante papel enquanto instrumento intencionalmente criado e indispensável para forjar ou ligar regiões/ localidades na lógica da globalização neoliberal e financeira. Com efeito, a utilização desse instrumento repercutirá profundamente na postura do Estado, pois criam "espaço de exceção" com interesse de estimular a produção industrial e as trocas comerciais com foco na obtenção de divisas.

Essa máxima é construída em nome de um aparato político-discursivo da promoção do desenvolvimento econômico do país. Desse modo, os governos passam a criar espaços diferenciados ou privilegiados para o restante do território nacional com leis e regras excepcionais de mercado, conforme destaca Ong (2004).

Como arrola Haesbaert (2014), presenciamos um novo processo de reconfiguração do Estado devido à hegemonia do capital financeiro; assim sendo, os países ou Estados nacionais, para ganharem relevância nesse "novo" cenário do mercado internacional, tornam-se mais "flexíveis". Isto porque os governos, ao adotarem esse tipo de instrumento, passam a coadunar seletivamente com formas neoliberais.

94 Essas formas neoliberais, de acordo com Ong (2006), mostram que os países com intenções de ingressarem nas redes de produção globais abrem mão de suas fronteiras ou soberania para criar certas facilidades, fragmentando e/ou dividindo seus territórios, o que representa um processo de "neoliberalismo de exceção". Os governos, ao adotarem esse tipo de política econômica, passam a coadunar seletivamente com a criação de espaços para o cálculo exclusivamente neoliberal, onde dominam de forma mais extremada as leis do mercado, como no caso das ZPEs.

As práticas neoliberais, segundo Ong (2006), desdobram uma estratégia sob a lógica de exceção, que é um processo de caráter espacial desigual, gradual e seletivo. A mesma autora ressalta que o ressurgimento da economia asiática, comandada pela China no cenário mundial, é resultado da criação desses espaços, como as ZPEs e as Zonas Econômicas Especiais (ZEEs), subsumidos estritamente sob a lógica de exceção.

Sendo assim, a partir das reflexões de Ong (2006, p. 19-20), podemos identificar algumas características e aspectos importantes das ZPEs:

Constituem espaços criados a partir de técnicas de escolhas calculistas institucionalizadas em mecanismo e produções, que assinalam espaços especiais de mercado de trabalho, oportunidade de investimento e relativa liberdade administrativa;

Impõem certas exceções ao neoliberalismo por mecanismos instrumentalizados de práticas e de controle espacializados sob legislação excepcionais; 

hierarquizado.

Surgem como um modelo de reforma de mercado que produz seletivamente espaços diferentes do restante do território nacional;

Permitem que essa medida de exceção crie um ambiente com certa administração espacial: a) de um lado, os Estados ou governos garantem-lhes certa "soberania formal" e; b) do outro lado, as empresas e instituições multilaterais passam a exercer ações de prática de controle (sobretudo de condições de trabalho, liberdade de negócios etc.) nesses espaços especiais criados.

No aparato político-discursivo, essa lógica tem como trunfo ideológico a ideia de os países buscarem um desenvolvimento econômico e sucesso competitivo no mercado global. Entretanto, os Estados passaram a dividir seus territórios, criando um tipo alternativo de territorialidade como uma espécie de "laboratório" da liberdade econômica e da atividade empresarial. Como ressalta Ong (2006, p. 19), "a lógica de exceção fragmenta a territorialidade humana no interesse de forjar conexões específicas, variáveis e contingentes aos circuitos globais".

Em suma, as ZPEs retratam um projeto neoliberal de integração vertical regional. Esses novos espaços flexíveis específicos realçam as mutantes geografias das relações de poder, isto é, as geometrias econômicas do poder, ligadas sob um modelo específico de desenvolvimento, em um sistema regional global altamente especializado e

Dessa forma, forjam-se conexões mais "flexíveis" de integração competitiva de determinados arranjos espaciais produtivos ou estruturas regionais com promessa de ingressarem nas redes de produção globais. Além disso, expõem o modo pelo qual determinados arranjos espaciais produtivos (regiões/localidades) reaparecem como instrumento estratégico de desenvolvimento frente aos novos imperativos do capitalismo, os quais se reproduzem na criação de novos espaços subsumidos por leis e regras excepcionais de mercado.

\section{Considerações finais}

Destarte, nossa abordagem permitiu demonstrar as complexas transformações em um mundo cada vez mais multifacetado e multiescalar, onde a conformação de um mercado está ligada ao processo de desintegração econômica vertical no âmbito internacional. Assim, as reestruturações econômicas e suas implicações nos diferentes arranjos espaciais produtivos se articulam em uma lógica geoestratégica de especialização e hierarquização que cria novas estratégias de desenvolvimento.

O desenvolvimento deste artigo permitiu compreender, ainda, que as ZPEs, face à sua estratégia global de expansão, reaparecem como instrumento alternativo para promover o desenvolvimento e, em particular, os chamados países subdesenvolvidos, em um contexto globalizante em via de reestruturação, em uma estratégia reforçada por uma postura discursiva e ideológica centrada na necessidade crescente da internacionalização de trocas, via ampliação do comércio internacional.

Nesse sentido, impõem-se mudanças na forma e prática institucional do Estado por meio da adoção de uma política nacional de desenvolvimento (sobretudo regional) mais flexível, através da qual os governos abrem suas fronteiras, delimitando localidades/ regiões com certa vocação para exportação ou que apresentem condições gerais de 
produção (CGP) diretamente ligadas ao processo de acumulação, com a finalidade de se integrarem por igual na fragmentação da produção.

\section{BIBLIOGRAFIA}

BENKO, G. Economia, Espaço e Globalização na Aurora do século XXI. São Paulo. Annablume, 2002.

BENKO, G. Economia urbana e regional na virada de século. In: RIBEIRO, M.T. F.; MILANI, C. R. S.

(Orgs). Compreendendo a complexidade socioespacial contemporânea: o território como categoria de diálogo interdisciplinar [online]. Salvador: EDUFBA, 2009.

BRANDÃO, C. Território e Desenvolvimento: as múltiplas escalas entre o local e o global. $2^{\underline{a}}$ edição. Campinas, SP: Editora da Unicamp, 2012.

CANO, W. Uma Agenda Nacional para o Desenvolvimento. Texto para Discussão. IE/UNICAMP, Campinas, n. 183, ago. 2010.

CHESNAIS, F. A mundialização do capital. São Paulo: Editora Xamã, 1996.

DICKEN, Peter. Mudança global - mapeando as novas fronteiras da economia mundial. Porto Alegre: Bookman, 2010.

EGLER, C. As escalas da economia: uma introdução à dimensão territorial da crise. Revista Brasileira de Geografia. vol.53, n.3, 1991, p. 229-245.

FERNÁNDEZ, R. V. Desenvolvimento regional sob transformações transescalares: porque e como recuperar a escala nacional? In: BRANDÃO, A, C.; FERNÁNDEZ, R. V.; RIBEIRO, Q. C. L. (Orgs.). Escalas Espaciais, Reescalonamentos e Estalidades: Lições e desafios para América Latina. 1. Ed. Rio de Janeiro: Letra Capital: Observatório das Metrópoles, 2018. pp. 276- 325.

FIAS. Special economic Zones Performance, Lessons Learned, and Implications for Zone Development. THE WORLD BANK GROUP, Abril 2008.

FUINI, L. L. Escola de regulação. In: SPOSITO, E. S (Org.) Glossário de Geografia Humana e Econômica. São Paulo: Editora Unesp, 2017.

GIL, A.; C. Como elaborar projetos de pesquisa. 4. ed. São Paulo: Editora Atlas, 2002. 173p.

HAESBAERT, R. Regional-Global - Dilemas da Região e da Regionalização na Geografia Contemporânea. Rio de Janeiro. Bertrand Brasil. 2010.

HAESBAERT, R. Viver no limite: território e multi/transterritorialidade em tempos de insegurança e contenção. Rio de Janeiro: Bertrand Brasil, 2014.

HARVEY, D. A condição pós-moderna. São Paulo: Loyola, 1989.

IGLIORI, D. C. Economia dos Clusters Industriais e Desenvolvimento. 1. ed. São Paulo: Iglu Editora, 2001.

LAN, D. Localização Industrial. In: SPOSITO, E. S (Org.) Glossário de Geografia Humana e Econômica. São Paulo: Editora Unesp, 2017. 
LENCIONI, S. Condições Gerais de Produção: Um Conceito a Ser Recuperado Para a Compreensão das Desigualdades de Desenvolvimento Regional. Revista Electrónica de Geografía y Ciencias Sociales. Vol. XI, núm. 245 (07), 1 de agosto de 2007.

LENCIONI, S. Condições Gerais de Produção. In: SPOSITO, E. S (Org.) Glossário de Geografia Humana e Econômica. São Paulo: Editora Unesp, 2017.

LIPIETZ, Alain. O capital e seu espaço. São Paulo: Ed. Nobel, 1988.

LIPIETZ, A. LEBORGNE, D. O pós-fordismo e seu espaço. Revista Espaço \& Debates, n.25. Ano VIII. 1988.

MARCONI, M. de A.; LAKATOS, E. M. Fundamentos de metodologia científica. 6. ed. São Paulo: Atlas, 2007.

MARX, K. Contribuição à crítica da economia política. 2 ed. São Paulo: Expressão Popular, 2008.

ONG, A. The Chinese Axis: Zoning Technologies and Variegated Sovereignty. Journal of East Asian Studies, vol. 4, no. 1, 2004.

ONG, A. neoliberalismo as exception: mutantions in citizenship and sovereignty. Durham e Londres: Duke University Press, 2006.

PAINTER, J. Governmentality and Regional Economic Strategies. In: HILLIER, J.; ROOKSBY, (Orgs.). Habitus: A Sense of Place. $2^{\text {nd }}$ edition. 2005. pp.131-157.

SANTOS, M. A Natureza do Espaço: Técnica e Tempo, Razão e Emoção. 4. ed. São Paulo: Editora da Universidade de São Paulo, 2006.

SANTOS, M. Pensando o espaço do homem. E. ed. São Paulo: Edusp, 2009.

SARTI, F.; HIRATUKA, C. Indústria mundial: mudanças e tendências recentes. Texto para Discussão. IE/UNICAMP n. 186, dezembro 2010.

SEN, A. Desenvolvimento como Liberdade. São Paulo. São Paulo: Companhia das Letras, 1999.

SILVA, C. A. F. Zona de Processamento de Exportações e Gestão do Território. Cadernos IPPUR/ UFRJ. Ano. VII, N. 2, Set. 1993a. 89-102p.

SILVA, C. A. F. A dimensão regional na gestão do território: da integração econômica à integração competitiva. Boletim Goiano de Geografia. Vol. 13 N. 1 Jan./Dez. 1993b. 4366p.

SOUZA, M. L. A teorização sobre o desenvolvimento em uma época de fadiga teórica, ou: sobre a necessidade de uma 'teoria aberta' do desenvolvimento "sócio-espacial". In: Revista Território, ano I, no 1. 1996. pp. 5-22.

SOUZA, M. L. Mudar a cidade: uma introdução crítica ao planejamento e à gestão urbanos, 8. ed. Rio de Janeiro: Ed. Bertrand Brasil, 2011. 560 p.

TEIXEIRA, A. C. Economia e Espaço: da questão regional à questão nacional. Campinas - SP, 2008. 197 f. (Tese de Doutorado) - Instituto de Economia da Universidade Estadual de Campinas, 2008.

UNCTAD. FDI in Services - A Growing Bussiness for EPZs. UNCTAD Investment Brief, n.2, 2004.

UNITED NATIONS CONFERENCE ON TRADE AND DEVELOPMENT. World Investment report, 2020. UNITED NATIONS CONFERENCE ON TRADE AND DEVELOPMENT. World Investment report, 2018 WONG, K.; CHU, D. K. Y. Export Processing Zones and Special economic Zones as Generators of Economic Development: The Asian Experirnce. Geografiska Annaler, Suécia, v. 66, n. 1, 1984. 
WORLD INVESTMENT REPORT. FDI in Services - A Growing Business for EPZs. UNCTAD

Investment Brief, Number 2, 2004.

\section{NOTAS}

1. De acordo com Gil (2002) e Marconi e Lakatos (2007), os trabalhos de análise documental podem ser de primeira e segunda mão. Os levantamentos em trabalhos de “primeira mão" são aqueles que ainda não receberam tratamentos analíticos (arquivos de instituições públicas e privadas e outros tipos de documentos). Os chamados de "segunda mão" são aqueles que, de alguma forma, receberam tratamento analítico (relatórios de pesquisa, relatórios de empresas, tabelas etc.).

2. Tais como: Harvey (1989) e Haesbaert; Porto-Gonçalves (2006).

3. O termo desenvolvimento é complexo, prenhe de juízo de valor, conforme Souza (1996; 2011). Peet (2009) e Touraine (2009) informam que o termo desenvolvimento advém das raízes políticofilosóficas da modernidade ocidental. Desse modo, ganhou força sem nenhuma discussão profunda no viés economicista, onde desenvolvimento é visto com um fim em si mesmo, em muitos casos como sinônimo de crescimento econômico. Nos termos centrais deste trabalho, desenvolvimento vai além dessa busca da maximização da renda, da riqueza e do aumento do PIB, estando relacionado à melhoria da vida e da liberdade para se fazer escolhas, conforme Sen (2000).

4. Há um entendimento geral na literatura que essa abordagem resgata o conceito de distritos industriais (industrial clusering) de Alfred Marshall (1920) ao depreender estudos da organização industrial e análise do desenvolvimento das indústrias (economia interna e externa). Em sua análise sobre economia externa (crescimento geral de um setor industrial), Marshall salientava o quesito de fundamental importância a localização da empresa. Dessa forma, no entendimento de Marshall, independentemente do tamanho das firmas os distritos e/ou aglomerações industriais, constituem vetor do progresso e de crescimento da população e da região, ou seja, o aumento geral da escala de produção (país), não está diretamente ligada ao porte das empresas, mas relacionadas com a localização e o relacionamento existente entre estas (IGLIORI, 2001).

5. O conceito de condições gerais de produção (CGP) tem origem no pensamento de Marx (2008). Lencioni $(2007$; 2017) tem retomado o debate do conceito de CGP, sobretudo na Geografia e insere a discussão sobre a ideia de consumo coletivo, porém com vistas a refletir sobre o consumo produtivo relacionado à indústria, ou melhor, à localização da atividade industrial. Para a referida autora, as CGP são agrupadas em dois conjuntos. O primeiro é composto pelos meios de circulação em conexões diretas com o processo de produção e circulação: bancos; alguns serviços; redes de circulação materiais, como rodovias, ferrovias, hidrovias; e redes de circulação imateriais, como de telecomunicações e de informática, assim, têm uma tendência de se desenvolverem em um ritmo mais acelerado em virtude de permitirem e/ou facilitarem a circulação de mercadoria e sua realização no mercado. O segundo conjunto agrega os meios de consumo coletivos em conexão indireta (escolas, hospitais etc.) com os processos de produção que ficam em segundo plano. No caso das ZPEs para serem implementadas as localidades/regiões devem apresentar vocação para a exportação, isto é, logo, devem oferecer uma adequada localização e CGP ligadas diretamente com o processo de produção e circulação do capital, seja do ponto de vista material (rodovias, ferrovias, hidrovias, portos e aeroportos), seja do ponto de vista imaterial (capital, telecomunicações etc.).

6. THE WORLD BANK. Export processing zones/Industry. Development Division, Industry and Energy Department [and] Trade Policy Division, Country Economics Department. Washington, D.C.1992. 
7. Chesnais (1996) em sua obra "A Mundialização do Capital" traz uma importante contribuição ao discutir o papel do IED nas especializações comerciais e chama a atenção para uma análise dos seus aspectos quantitativo e qualitativo. O autor define duas formas dos investimentos estrangeiros: primeiro, o investimento direto, aquele no qual o investidor detém $10 \%$ ou mais das ações ordinárias ou do direito de voto numa empresa e que também estimula investimento a longo prazo, permitindo ao seu proprietário exercer influência sobre as decisões de gestão da empresa; segundo, o investimento em carteira, que corresponde ao conjunto dos depósitos bancários e das aplicações financeiras sob a forma de títulos públicos ou privados. No caso específico das ZPEs, a principal prioridade desses tipos de investimentos preconizados é referente ao Investimento Estrangeiro Direto.

8. Dicken (2010) trata da interligação crescente na economia global e considera os IEDs um elemento chave para essa interligação crescente à economia global, isso entre 1950 e o fim do século XX. O autor define investimento direto como ações realizadas pela empresa em outra cuja finalidade é de obter um grau de controle sobre as operações dessa empresa. Investimento direto externo corresponde a um investimento direto através das fronteiras nacionais, tais ações visam a um investimento de controle em uma empresa em outro país.

\section{RESUMOS}

Este artigo analisa a definição e a ação político-discursiva global relacionadas à expansão de Zona de Processamento de Exportações - ZPEs em diferentes países como estratégia para promover o desenvolvimento em um contexto marcado pelo processo de reestruturação econômica. Em termos metodológicos, realizou-se um levantamento bibliográfico, propiciando construir um arcabouço das diversas perspectivas acerca da problemática em questão, e uma análise com base em fontes documentais - "de primeira e segunda mão" - sobre as ZPEs disponibilizadas em sítios web oficiais, tais como: United Nations Conference on Trade and Development (UNCTAD), The Word Bank (Banco Mundial); Ministério do Desenvolvimento, Indústria e Comércio Exterior (MDIC), Conselho Nacional das Zonas de Processamento de Exportação (CZPE) e Associação Brasileira de Zonas de Processamento de Exportação (ABRAZPE). A utilização das Zonas de Processamento de Exportações (ZPEs) como modelo político e econômico no mundo não é recente, porém teve uma expansão global enquanto instrumento de desenvolvimento econômico em diversas regiões do mundo (EUA; União Europeia; Ásia, África e nas Américas Central e do Sul) a partir da última metade do século XX. Duas forças são preconizadas para a difusão das ZPEs, quais sejam: como ferramenta de política econômica industrial e como estratégia alternativa de política industrial e de desenvolvimento pelos governos dos países subdesenvolvidos como forma de solução para os problemas econômicos, sociais e regionais. Assim, considera-se à expansão ZPEs como estratégia e ação seletiva, assimétrica e hierárquica.

This article analyses the definition and global political-discursive action related to the expansion of the Export Processing Zone - EPZs in various countries as a strategy to foster development within a context shaped by the process of economic restructuring. Methodologically, a bibliographical survey was carried out, promoting the building of a framework from different perspectives on the issue at hand, and an analysis based on documentary sources - "first and second-hand" - on EPZs available on official websites, such as: United Nations Conference on Trade and Development (UNCTAD), The Word Bank (Banco Mundial); Ministry of Development, Industry 
and Foreign Trade, National Council of Export Processing Zones (EPZs) and Brazilian Association of Export Processing Zones (ABRAZPE). The use of Export Processing Zones (EPZs) as a political and economic model in the world is not recent, but it has expanded globally as a tool for economic development in several regions (USA; European Union; Asia, Africa and Central and South America) from the last half of the 20th century onwards. Two forces are advocated for the dissemination of EPZs, which ones are: as an industrial policy tool and as alternative strategy of industrial and development by the governments of the underdeveloped countries as a way of solving economic, social and regional problems. Thus, it considers the expansion of EPZs as a selective, asymmetric and hierarchical strategy and action.

Este artículo analiza la definición y la acción político-discursiva global relacionadas a la expansión de Zona de Procesamiento para las Exportaciones - ZPEs en distintos países como estrategia para impulsar el desarrollo en un contexto marcado por el proceso de reestructuración económica. A nivel metodológico, se llevó a cabo un levantamiento bibliográfico, propiciando construir un marco de las diversas perspectivas acerca de la problemática en cuestión, y un analisis con base en fuentes documentales - "de primeira y segunda mano" - sobre las ZPEs disponibles en sítios web oficiales, así como: United Nations Conference on Trade and Development (UNCTAD), The Word Bank (Banco Mundial); Ministerio de Desarrollo, Industria y Comercio Exterior (MDIC), Consejo Nacional de Zonas de Procesamiento de Exportación (CZPE) y Asociación Brasileña de Zonas de Procesamiento de Exportación (ABRAZPE). La utilización de las Zonas de Procesamiento de Exportaciones (ZPEs) como modelo político y económico en el mundo no es reciente, sin embargo ha tenido una expansión global mientras instrumento de desarrollo económico en las diversas regiones del mundo (EUA; Unión Europea; Asia, África, en las Américas Central y del Sur) a partir de la última mitad del siglo XX. Dos fuerzas son preconizadas para la difusión de las ZPEs, sean tales: como herramienta de política económica industrial y como estrategia alternativa de política industrial y de desarrollo por los gobiernos de los Países em Desarrollo - PEDs como forma de solución para los problemas económicos, sociales y regionais.

Cet article analyse la définition et l'action politico-discursive globale liée à l'expansion des zones franches D'exportation - ZPEs dans différents pays comme stratégie de promotion du développement dans un contexte marqué par le processus de restructuration économique. Sur le plan méthodologique, une enquête bibliographique a été réalisée, permettant de construire un cadre des différentes perspectives sur le problème en question, et une analyse basée sur des sources documentaires - " de première et de seconde main " - sur les ZPEs mis à disposition sur les sites officiels, tels que: United Nations Conference on Trade and Development (UNCTAD), The Word Bank (Banque mondiale) ; Ministère du Développement, de L'industrie et du Commerce Extérieur (MDIC), Conseil National des Zones franches D'exportation (CZPE) et Association Brésilienne des Zones franches D'exportation (ABRAZPE). L'utilisation des Zones franches D'exportation (ZPEs) comme modèle politique et économique dans le monde n'est pas récente, mais elle a connu une expansion mondiale en tant qu'instrument de développement économique dans plusieurs régions du monde (États-Unis; Union Européenne; Asie, Afrique et Amérique centrale et du Sud) à partir de la dernière moitié du XXe siècle. Deux forces sont recommandées pour la diffusion des ZPEs, à savoir: comme instrument de politique économique industrielle et comme stratégie alternative de politique industrielle et de développement par les gouvernements des pays soudéveloppés comme moyen de résoudre les problèmes économiques, sociaux et régionaux. Ainsi, l'expansion des ZPEs est considérée comme une stratégie et une action sélectives, asymétriques et hiérachiques. 
ÍNDICE

Palabras claves: ZPEs, Desarrollo, Reestructuración económica.

Mots-clés: ZPEs, Développement, Reestructuration économique.

Palavras-chave: ZPEs, desenvolvimento, Restruturação econômica

Keywords: EPZs, Developments, Economic restructuring.

\section{AUTORES}

\section{JEAN DA SILVA CRUZ}

Doutor em Geografia pelo Programa de Pós-Graduação em Geografia da Faculdade de Ciências e Tecnologia, Universidade Estadual Paulista Júlio de Mesquita Filho (FCT/UNESP - Campus de Presidente Prudente). ORCID:0000-0002-4844-6146

\section{ANTONIO NIVALDO HESPANHOL}

Docente dos cursos de Graduação e de Pós-Graduação em Geografia da Faculdade de Ciências e Tecnologia da UNESP, Campus de Presidente Prudente. Bolsista produtividade em pesquisa, nível 2, do CNPq e atual presidente da Fundação Vunesp. ORCID: 0000-0001-5080-0223 